\title{
ENDOMETRIOMA IR DERMOIDINE் CISTA VIENOJE KIAUŠIDĖJE: KLINIKINIS ATVEJIS
}

\author{
Indrè Tavorait $\dot{e}^{1}$, Daiva Bartkevičienè $\dot{2}^{2}$ \\ ${ }^{1}$ Vilniaus universiteto Medicinos fakultetas, ${ }^{2}$ Vilniaus universiteto Medicinos fakulteto \\ Klinikinès medicinos instituto Akušerijos ir ginekologijos centras
}

Raktažodžiai: endometrioma, teratoma, dermoidas, kompleksinis kiaušidès darinys.

\begin{abstract}
Santrauka
Straipsnyje aprašomas retas klinikinis atvejis, kai 34 metu moteriai atsitiktinai nustatytas endometriomos ir brandžios cistinès teratomos kompleksinis darinys iki $12 \mathrm{~cm}$ kairiojoje kiaušidèje. Be gausesnių mènesinių, pacientei nepasireiškė jokių tipinių gimdos priedų auglių simptomų. Atlikta laparoskopinè cistektomija, o histologinis tyrimas patvirtino diagnozę. Nors endometriomų ir dermoidų paplitimas ikimenopauzinio amžiaus moterų populiacijoje didelis, kompleksinis šių cistų darinys vienoje kiaušidèje susiformuoja retai. Pubmed duomenų bazejje buvo rasta 11 panašių atvejų aprašymų. Dauguma nekomplikuotų dermoidų nesukelia simptomų, tačiau tik trečdalis endometriozès atvejų yra besimptomiai. Diagnostikai pasitelkiami ultragarso bei magnetinio rezonanso tomografijos tyrimai. Gydymo taktikos pasirinkimas priklauso nuo amžiaus, simptomų išreikštumo bei kiaušidès cistos matmenų. Vaisingo amžiaus pacientėms rekomenduojama laparoskopine cistektomija, stengiantis išsaugoti liekamajj kiaušidès rezervą ir reprodukcinę funkciją.
\end{abstract}

\section{İvadas}

Kiaušidžių gerybiniai dariniai, ypač teratomos ir endometriomos, yra vienos iš dažniausiai ginekologinejje praktikoje diagnozuojamų patologijų. Endometriozė yra gerybiné ginekologinè liga, kuriai būdingas heterotopinis endometriumo liaukų ir audinio augimas. Kiaušidès endometrioma - cistinè endometriozès išraiška kiaušidèse, dèl tamsaus tiršto turinio dar vadinama šokoladine cista. Brandžios gerybinès kiaušidžių teratomos (dermoidai) yra lètai progresuojantys cistinès struktūros germinaciniai navikai, susiformuojantys iš kamieninių ląstelių. Jų sudètyje aptinkama ịvairių audinių pẻdsakų - odos ir jos priedų, dantų, kaulų, raumenų, glijos audinių, virškinamojo trakto ar kvèpavimo takų epitelio ir kitų $[1,2]$.
Teratomos sudaro $20-25$ proc. visų kiaušidžių navikų, o cistinè brandi gerybinè teratoma (dermoidas) yra dažniausias teratomos variantas. Endometriozès paplitimas varijuoja nuo 1 iki 5 proc. bendroje moterų populiacijoje [3,4]. Maždaug dviem iš trijų moterų, sergančių endometrioze, kiaušidèse diagnozuojamos endometriomos [1]. Nors minètų patologijų paplitimas vaisingo amžiaus moteru populiacijoje gana aukštas, jų išsivystymas kartu vienoje kiaušidèje yra retas atvejis, o PubMed duomenų bazèje nuo 1960 metų registruota tik 11 panašių atvejų aprašymų. Viename organe esantys skirtingos etiopatogenezès ir požymių dariniai kelia iššūkius operuojančiam bei konsultuojančiam ginekologui.

Tyrimo tikslas - aprašyti Vilniaus universiteto ligoninès Santaros klinikose nustatytos endometriomos ir dermoidinès cistos vienoje kiaušideje atveji, gydymo eigą bei rezultatus. Remiantis klinikiniu atveju ir moksline literatūra, apžvelgti šių patologijų priežastis, klinikinius požymius, diagnostiką, gydymo galimybes bei prognozę.

\section{Tyrimo rezultatai}

Klinikinio atvejo aprašymas. 2020 metų gruodžio mènesị 34 metų moteris po profilaktinio ginekologinio ištyrimo poliklinikoje nusiųsta trečio lygio ginekologo konsultacijai dèl įtariamos kairiosios kiaušidès endometriozès. Pacientè simptomų nejuto, mènesinių ciklas reguliarus, tačiau pagausèjęs kraujavimas. Ginekologinių operacijų, nėštumų ir gimdymų nebuvo. Gretutinemis ligomis nesirgo. Laboratorinių imunofermentinių tyrimų rezultatai parodè padidejusị véžio žymeni CA-125 (129,6 kU/l; norma <35 kU/l). Pagal ROMA indeksą ikimenopauzinio amžiaus moterims, pacientei nustatyta maža $(5,1$ proc.) kiaušidžių piktybinio naviko rizika, o epitelinio kiaušidžiu vėžio žymuo HE4 buvo normos ribose. Transvaginalio ultragarsinio tyrimo metu buvo stebimi du cistiniai dariniai kairiojoje kiaušideje: 6,77 x 6,01 $\mathrm{cm}$ dydžio nehomogeniškas grūsto stiklo vaizdo darinys be kraujotakos bei $6,13 \times 5,18 \mathrm{~cm}$ dydžio mišrios echostruktūros su echopozityviais intarpais cistinis darinys be kraujotakos 
(1 pav.). Atliktas magnetinio rezonanso tomografijos (MRT) tyrimas su intraveniniu kontrastavimu patvirtino diagnoze (2 pav.). Dešiniau už gimdos esantis didelių matmenų $(45,1$ x 55,3 x 76,4 mm) dermoido darinys buvo sudarytas iš didelio kiekio riebalinio audinio, centrineje dalyje buvo heterogeninių struktūrų su solidiniais, skysčio bei kalcinatų komponentais. Kairiau už gimdos vizualizuotas plonasienis cistinis $63,3 \times 66,6 \times 70,2 \mathrm{~mm}$ darinys homogenišku turiniu - endometrioma.

Pasirinkta operacinio gydymo taktika - planinè laparoskopinè cistektomija endotrachejjinejje nejautroje. Pooperacinis laikotarpis be komplikacijų. Histologinio tyrimo atsakymas - endometrioidinè kiaušidès cista ir brandi cistinè teratoma.

Literatūros apžvalga. Nors endometriomos ir brandžios teratomos yra dažnos ginekologinès problemos vaisingų moterų populiacijoje, abu augliai vienoje kiaušidèje išsivysto retai. PubMed duomenų bazejje buvo surasta 11 panašių klinikinių atvejų aprašymų. Anksčiausiai E. Ferrario ir kt. [5] aprašytas atvejis buvo 1960 metais. 1 lentelèje pateikiami literatūroje rastų endometriomos ir teratomos vienoje kiaušidejje atvejų aprašymo duomenys. Pristatomu atveju pacientès amžius diagnozès nustatymo metu buvo 34 metai, kuris atitinka anksčiau aprašytu atvejų amžiaus amplitudę, varijuojančią nuo 22 iki 35 metų. Šešiais iš devynių atvejais kompleksiniai endometriomos ir teratomos dariniai susiformavo kairiojoje kiaušidejje, kaip ir šiuo atveju. Lyginant klinikinį pasireiškimą, šis atvejis panašus tik į L.Taylor ir kt. [6] aprašytaji, kai nèštumo metu cistinis darinys rastas atsitiktinai, pacientei nejaučiant jokių skausmų. Dažniausiai taikytas operacinis gydymo būdas buvo laparoskopinè cistektomija, išsaugant kiaušidę. Histologinio tyrimo metu dažniausiai buvo patvirtinamas brandžios cistinès teratomos ir endometriomos kompleksas, tačiau pasitaikè atvejų, kai

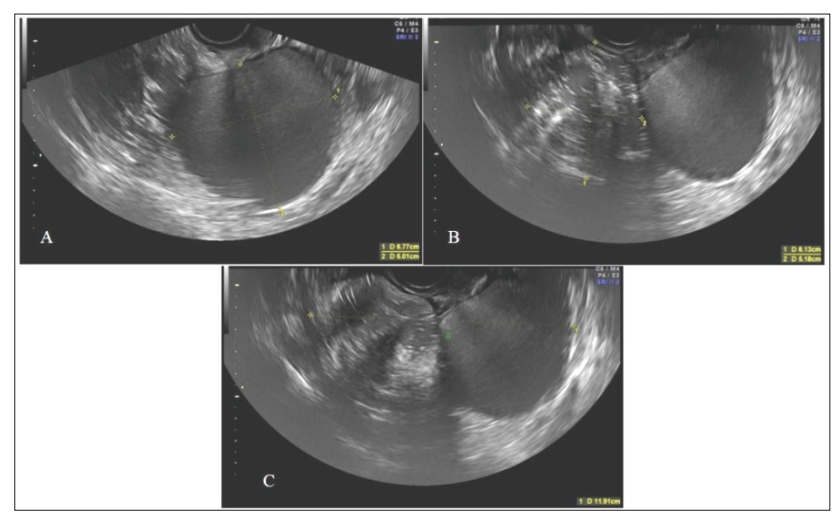

1 pav. Transvaginalio dubens organų ultragarsinio tyrimo nuotraukos: A - 6,77 x 6,01 cm dydžio endometrioidinè cista; $\mathrm{B}-6,13$ x $5,18 \mathrm{~cm}$ dydžio dermoidinè cista; $\mathrm{C}$ - bendras dvigubo cistinio darinio ilgis $-11,91 \mathrm{~cm}$ kartu buvo identifikuotas retas teratomos tipas, sudarytas iš skydliaukès audinio, struma ovarii ar mucinine cistadenoma.

H. Chae ir kt. [15] 2020 metais atlikto tyrimo išvadose teigiama, jog kartu išsivystančių endometriomų ir brandžiu teratomų atvejų galbūt nèra tiek mažai, kaip buvo manyta. I tyrimą buvo įtraukta 71 moteris: 55 patvirtinta brandi cistinè kiaušidès teratoma, 16 - ir teratoma, ir endometriozè (komplekso grupė), iš kuriu penkiais atvejais abu cistiniai dariniai buvo vienoje kiaušidejje. Atsižvelgiant ị klinikinę išraišką, komplekso grupejje dismenorèjos simptomai buvo dažniausias nusiskundimas ir pasireiške statistiškai reikšmingai dažniau, nei teratomos grupejje (atitinkamai 43,8 ir 7,3 proc.). Dauguma pacienčių teratomos grupejje nejautė jokių simptomų, kas suponavo hipotezę, jog esant kiaušidès dermoido diagnozei ir išreikštiems dismenorejos simptomams, galètų būti įtariama ir esanti, tačiau dar nevizualizuojama, endometriozè.

Etiopatogenezé. Viena iš labiausiai paplitusių endometriozès teorijų - Sampson teorija. Ji teigia, jog menstruaciju metu endometriumo ląstelès juda retrogradiškai, per kiaušintakius patenka ị pilvo ertmę, įsitvirtina ant pilvaplèvès ar dubens organų ir taip formuoja heterotopini endometriumo židinị. Tipinès endometriozès vietos ir yra aplink kiaušintakių angas dubenyje, kiaušidėse, aplinkiniuose raiščiuose, pilvo ertmejje, riestinèje žarnoje, apendikse [16]. Endometriozès riziką didina chirurginès procedūros. Cezario operacija endometriozès riziką didina net du kartus, o gimdymas natūraliais takais šią riziką mažina [17]. Teigiama šeiminè anamnezè ir

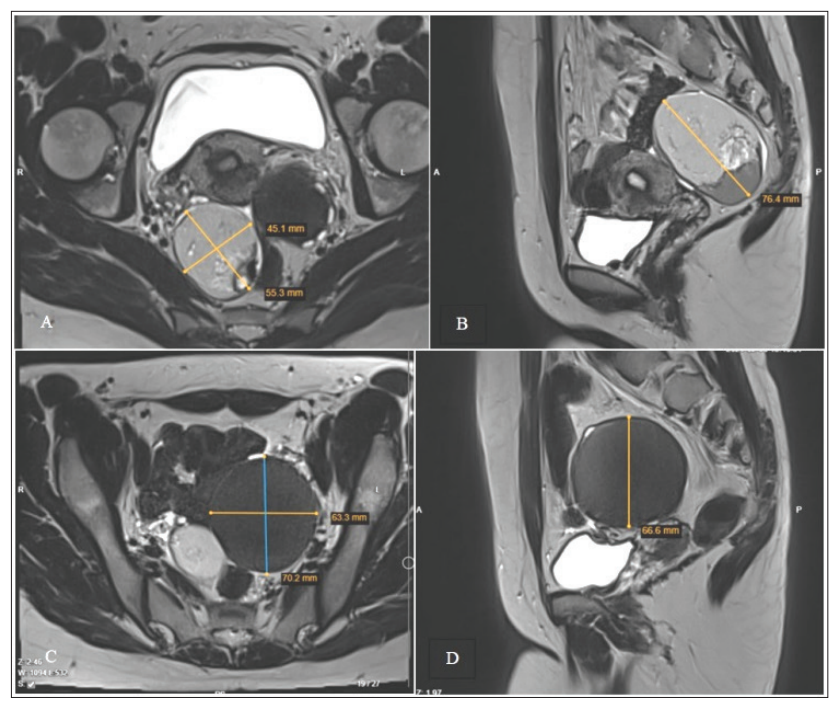

2 pav. MRT tyrimo vaizdai, T2 TSE (turbo spin echo) sekos: A,B - dermoidinè cista skersinèje ir strèlinèje plokštumose, hiperintensinio signalo; C, D - endometrioma skersinèje ir strèlinèje plokštumose, hipointensinio signalo 
genetinè predispozicija siejama su spartesniu endometriozès vystymusi jaunesniame amžiuje [1]. Kiti rizikos veiksniai yra trumpas menstruacinis ciklas ( $\leq 27 \mathrm{~d}$.), pastovus gausus kraujavimas per menstruacijas, žemas kūno masès indeksas [3]. Gausesnis menstruacinis kraujavimas ir tai, kad paciente negimdžiusi, galètų kelti didesnę endometriozès riziką.

Kiaušidžių endometriomų susiformavimas aiškinamas keliomis teorijomis. Kraujuojant paviršiniams endometriozès židiniams kiaušidèje, ilgainiui galètų būti sukeliama žievinio sluoksnio inversija bei invaginacija, taip suformuojant cistą. Endometriomos galètų susidaryti į endometriozès židinius įtraukiant funkcines kiaušidès cistas. Endometriomų patogenezę gali paaiškinti ir Meyer teorija - endometrioidinès cistos galètų susiformuoti kiaušidès epiteliui metaplazavus i funkciškai aktyvų endometriumo audinį [18].

Teratomų patogenezė skiriasi nuo endometriomų. Germinaciniai navikai kyla ne iš somatinių, o iš kamieninių ląstelių. Augliai pradeda formuotis po pirmojo mejozinio kamieniniu ląstelių pasidalijimo ir suformuoja 46,XX kariotipą [1]. Yra keli tipiniai teratomų pasireiškimo laikotarpiai: iki dvejų metų ir vẻlyvoje paauglystejje (jaunysteje). Pirmuoju laikotarpiu, ypač iki 4 mėnesių, diagnozuojamos įgimtos gerybinès teratomos, o antruoju pasireiškia prenataliniu laikotarpiu susiformavę, tačiau lètai augantys augliai [2].
Klinikiniai požymiai. Didžiojoje Britanijoje atlikto nacionalinio tyrimo rezultatai parodè, kad endometriozè dažniausiai pasireiškia dismenorèja, dispareunija ir skausmu dubens srityje [3]. Endometrioze sergančioms moterims sunkiau ar nepavyksta pastoti, dažnesnè menoragija. Kiaušidžių endometriomos gali pasireikšti pilvo skausmu pažeistos kiaušidès pusejje ar plintančiu per visą pilvą. Endometriomos plyšimo atveju tirštas turinys išplinta pilvo ertmèje, sukeldamas uždegimą ir stiprius skausmus, kurie reikalingi skubaus ištyrimo ir gydymo [19]. Nors endometriozè gali pasireikšti įvairaus spektro bei labai ryškiais simptomais, maždaug vienam trečdaliui pacienčių ši liga būna be simptomų [1]. Dermoidinès cistos iki 60 proc. atvejų yra asimptomès ir diagnozuojamos atsitiktinai profilaktinio ištyrimo metu. Kartais pasireiškia simptomai - pilvo skausmas, spaudimo jausmas. Būklei komplikavusis, išryškèja ūmus stiprus pilvo skausmas, kartais lydimas pykinimo ir vėmimo [1]. Nors pristatomu atveju pacientei buvo diagnozuotas didelių matmenų cistinis darinys dubenyje, ji neturejo kitų skundų, išskyrus gausesnes mènesines.

Gerybinių gimdos priedų auglių apsisukimas kartu su kiaušide yra viena dažniausių komplikacijų. D. Houry ir kt. [20] tyrimo išvados sutampa ir su kitų apžvalgų duomenimis - daugiau, nei 80 proc. kiaušidès apsisukimo atvejų įvyko,

1 lentelè. Endometriomos ir teratomos vienoje kiaušidèje atvejų apžvalga.

* Duomenu bazèje pateikiama tik santrauka.

\begin{tabular}{|c|c|c|c|c|c|}
\hline $\begin{array}{l}\text { Autoriai, } \\
\text { metai }\end{array}$ & Amžius & Simptomai & $\begin{array}{c}\text { Kiaušidė su } \\
\text { kompleksiniu } \\
\text { dariniu }\end{array}$ & Operacinis gydymas & Histologinė diagnozė \\
\hline $\begin{array}{l}\text { Ferrario ir kt., } \\
1960[5]^{*}\end{array}$ & 23 & Nėra duomenų & Nenurodo & $\begin{array}{l}\text { Abipusė salpingo-ovarekto- } \\
\text { mija }\end{array}$ & Dermoidinè cista ir endometrioma \\
\hline $\begin{array}{l}\text { Caruso ir kt., } \\
1997[7] *\end{array}$ & 28 & Pilvo skausmas & Kairioji & $\begin{array}{l}\text { Kairioji cistektomija, deši- } \\
\text { nioji ovarektomija }\end{array}$ & $\begin{array}{l}\text { Dermoidinė cista abipus ir endome- } \\
\text { trioma kaireje }\end{array}$ \\
\hline $\begin{array}{l}\text { Frederick ir } \\
\text { kt., } 2003[8] *\end{array}$ & \begin{tabular}{|l|} 
Nenu- \\
rodo \\
\end{tabular} & $\begin{array}{l}\text { Nevaisingumas, dis- } \\
\text { menorèja }\end{array}$ & Nenurodo & Laparoskopinė cistektomija & $\begin{array}{l}\text { Dermoidinè cista abipus ir endome- } \\
\text { trioma }\end{array}$ \\
\hline $\begin{array}{l}\text { Van der Merwe } \\
\text { ir kt., } 2010[9]\end{array}$ & 30 & Pilvo pūtimas & Dešinioji & Dešinioji ovarektomija & $\begin{array}{l}\text { Dermoidinė cista, endometrioma, } \\
\text { mucininè cistadenoma }\end{array}$ \\
\hline $\begin{array}{l}\text { Chen ir kt., } \\
2011[10]\end{array}$ & 35 & $\begin{array}{l}\text { Pilvo skausmas, py- } \\
\text { kinimas, dismenorejja }\end{array}$ & Dešinioji & Laparoskopinè cistektomija & Dermoidine cista ir endometrioma \\
\hline $\begin{array}{l}\text { Prorocic ir kt., } \\
2013[11]^{*}\end{array}$ & 33 & Nenurodo & Kairioji & Laparoskopinė cistektomija & Dermoidiné cista ir endometrioma \\
\hline $\begin{array}{l}\text { Taylor ir kt., } \\
2015[6]\end{array}$ & 33 & $\begin{array}{l}\text { Nustatyta vizito dèl } \\
\text { nèštumo metu }\end{array}$ & Dešinioji & $\begin{array}{l}\text { Cezario operacija ir salpingo- } \\
\text { ovarektomija }\end{array}$ & Dermoidinè cista ir endometrioma \\
\hline $\begin{array}{l}\text { Chae ir kt., } \\
2015[12]\end{array}$ & 28 & $\begin{array}{l}\text { Diskomfortas pilve, } \\
\text { kraujavimas }\end{array}$ & Kairioji & Laparoskopinė cistektomija & $\begin{array}{l}\text { Dermoidinė cista abipus ir endome- } \\
\text { trioma kaireje }\end{array}$ \\
\hline $\begin{array}{l}\text { Hwang ir kt., } \\
2018[13]\end{array}$ & 22 & Šono skausmas & Kairioji & Laparoskopinė cistektomija & $\begin{array}{l}\text { Dermoidinè cista, struma ovarii abi- } \\
\text { pus ir endometrioma kairèje }\end{array}$ \\
\hline \multirow[t]{2}{*}{$\begin{array}{l}\text { Kiyak ir kt., } \\
2019[14]\end{array}$} & 25 & $\begin{array}{l}\text { Nevaisingumas, dis- } \\
\text { menorëja }\end{array}$ & Kairioji & Laparoskopinè cistektomija & Dermoidine cista ir endometrioma \\
\hline & 22 & Dismenorèja & Kairioji & Laparoskopinė cistektomija & Dermoidiné cista ir endometrioma \\
\hline
\end{tabular}


kai kiaušidès dydis dèl gerybinių auglių buvo didesnis, nei $5 \mathrm{~cm}$. Dažniausios apsisukimo priežastys buvo kiaušidžių hemoraginès cistos, gerybinès brandžios teratomos ir serozinès cistadenomos.

Diagnostika. Esant endometriozei, klasikinis kiaušidžių vėžio žymuo CA-125 dažniausiai esti aukščiau normos ribos bei kyla, ligai progresuojant. Šio žymens žemas specifiškumas, nes jis būna padidèjęs ir esant lejomiomoms, uždegiminei dubens ligai ar pirmo néštumo trimestro metu [1]. Žmogaus prielipo baltymo 4 (HE4), kaip perspektyvaus kiaušidžių vėžio žymens nauda, yra pripažinta. HE4 ne tik papildo CA-125, bet galimai yra tikslesnis žymuo, prognozuojant atsinaujinimą ir išgyvenamumą, sergant kiaušidžių vèžiu [21].

İtariant gimdos priedų darinius ikimenopauzinio amžiaus pacientèms, be išreikštų simptomų, pirmiausia turètų būti taikomas transvaginalinis arba transabdominalinis ultragarsinis tyrimas kartu su Doppler režimu. Diagnozès tikslinimui rekomenduojamas MRT tyrimas [22]. Endometriomą kiaušidèje galima ịtarti nustačius vienkamerinę plonasienę be išreikštos kraujotakos cistą su nehomogenišku grūsto stiklo vaizdo turiniu. Rečiau susiformuoja solidinių komponentų turinčios ar daugiakamerinès cistos [23]. MRT tyrimo T1 sekoje endometrioma dažniausiai yra hipointensinio signalo. T2 sekoje endometrioma yra hipointensinio signalo dèl kraujo ir hemoglobino sankaupų [24]. Brandžios gerybinès teratomos ultragarsinio tyrimo metu vizualizuojamos kaip cistiniai, solidiniai ar kompleksiniai dariniai, be išreikštos kraujotakos. Plaukų komponentai suformuoja plonas daugines hiperechogeniškas linijas, kalcifikatai ir dantys išsiskiria hiperechogeniškumu ir formuojamais šešèliais, o cistoje esantys skysčiai ir riebalai formuoja matomą liniją. Dermoidai MRT tyrimo T1 sekose yra hiperintensyvaus signalo, o T2 sekose - vidutiniškai intensyvaus ar hiperintensyvaus signalo. Pasitelkiant riebalų supresijos sekas, identifikuojami riebaliniai teratomos komponentai [25].

Gydymas. Remiantis Kanados akušerių ir ginekologu draugijos (angl. The Society of Obstetricians and Gynaecologists of Canada, SOGC) gairemis apie gerybinių kiaušidžiu augliu gydymo taktiką [26], asimptominiai kiaušidžių dariniai iki $10 \mathrm{~cm}$, ultragarsu įvertinti kaip gerybiniai, gali būti gydomi konservatyviai. Simptominiai gerybiniai kiaušidžiu augliai, nustatyti ikimenopauzinio amžiaus moterims, turètų būti pašalinti. Remiantis tuo, jog pacientei buvo nustatytas beveik $12 \mathrm{~cm}$ kompleksinis cistinis gerybinis kiaušidžių darinys, operacinio gydymo taktika buvo pasirinkta teisingai.

Laparoskopinè taktika SOGC gairèse nurodoma kaip tinkamiausia iš visų galimų simptominiams kiaušidžių dariniams, nes šiuo metu tai ne tik techniškai lengvai atliekama bei saugu, bet ir sudaro sąlygas trumpesniam hospitalizacijos laikui, greitesnei reabilitacijai. Lyginant su laparotomija, nustatyti mažesni kraujavimo bei pilvo skausmo dažniai. Rekomenduojama, jog laparoskopijos procedūra ịtrauktų ir gretimų struktūrų ịvertinimą. Be gimdos, kiaušintakių ir kiaušidžių turètų būti apžiūrèta ir šlapimo pūslè, kirmèlinè atauga, pilvaplèvè, viršutinis pilvo ertmès aukštas. Laparoskopijos procedūra yra ilgesne, o jos metu didesnè cistų turinio išsiliejimo, ląstelių išsisejjimo ir peritonito išsivystymo tikimybè. Laparoskopinè cistektomija - geresnis pasirinkimas kiaušidžiu auglių šalinimui nei fenestracija, aspiracija ar lazerinè technika. Naudojant aspiracijos metu paimtą skystį, neịmanoma patikimai atmesti darinio piktybiškumo, o fenestracija siejama su didesniu cistų pasikartojimo dažniu, nei atliekant cistektomiją [26].

Šiuo metu aktuali ir daugelyje tyrimų nagrinèjama tema yra kiaušidžių funkcinio ir reprodukcinio rezervo sumažejjimas po cistektomijos, kuris vertinamas pagal antimiulerinio hormono (AMH) koncentracijos pakitimus kraujo serume. Šio hormono svyravimas mentruacinio ciklo metu nèra toks išreikštas, kaip kitų, todèl itin tinkamas stebejimui. Tiek endometriomų, tiek dermoidų operacinis pašalinimas lemia statistiškai reikšmingą AMH sumažèjimą ir kiaušidžiu rezervo pažaidą $[27,28]$. Pašalinus didelio diametro kiaušidžių cistas $(>5 \mathrm{~cm})$, galima tikètis statistiškai reikšmingo AMH sumažèjimo [29]. Šiai pacientei nustatytas didelių, iki $12 \mathrm{~cm}$ matmenų, kiaušidès endometriomos ir dermoido darinys. Tyrimų duomenimis, tokio dydžio ir histologinių tipų kompleksinès cistos pašalinimas turèjo reikšmingą poveikị šios pacientės liekamajam kiaušidžių rezervui ir reprodukcijos galimybèms.

Prognoze. M. Kostrzewa ir kt. [30] retrospektyviai ištyré aktyviai bandančių pastoti moterų vaisingumą 24 ménesių laikotarpiu po laparoskopinès cistektomijos. Duomenys parodé, jog vaisingumas po laparoskopinių operacijų dèl gerybinių kiaušidžių cistų yra žemas (42,28 proc.). Endometriomų grupejje nėštumų dažnis buvo reikšmingai mažesnis, nei kitų cistų grupejje, kurių didžiausią dalị sudare brandžios teratomos (atitinkamai 32,3 ir 52,6 proc.).

Po gimdos priedų auglių pašalinimo itin svarbu stebejjimas. Atsinaujinančios kiaušidžių cistos - viena pagrindinių nevaisingumo priežasčiu moterims, gydytoms laparoskopinès cistektomijos būdu. Endometriomų pasikartojimas beveik du kartus dažnesnis, nei kitų kiaušidžių cistų (atitinkamai 36,3 ir 19,3 proc.) [30]. Dermoidų pasikartojimo dažnis yra 3 - 4 procentai [31].

\section{Išvados}

1. Endometriomos ir dermoidinès cistos yra dažnos ligos vaisingo amžiaus moterų populiacijoje, tačiau kompleksinis šių cistų darinys vienoje kiaušidejje susiformuoja retai. 
2. Endometriomos bei dermoidai gali sukelti pilvo skausmus ar dismenorejją, tačiau šis atvejis iš kitų panašių duomenų bazèse rastų atvejų išsiskiria tuo, kad paciente nejaute jokių tipinių simptomų.

3. Pagrindinis diagnostikos metodas yra ultragarsinis tyrimas, o patikslinama atliekant magnetinio rezonanso tyrimą.

4. Gydymo taktika priklauso nuo cistų dydžio bei sukeliamų simptomų, tačiau tinkamiausias gydymas vaisingo amžiaus moterims yra kiaušidžių audinị tausojanti laparoskopinè cistektomija. Kiaušidžių audinio rezervo sumažejjimas po cistektomijos yra aktuali ir plačiai nagrinejjama tema. Moterų nèštumo dažnis po cistektomijos yra žemas.

\section{Literatūra}

1. Lobo R, Gershenson D, Lentz G, Valea FA. Comprehensive Gynecology. 7th Edition, Elsevier 2016:968. https:/wwwclinicalkey-com.ezproxy.dbazes.1smuni.1t/\#!/browse/book/3s2.0-C20130004094

2. Kumar VK. Robbins \& Cotran pathologic basis of disease. 9th Edition, Elsevier 2021.

3. Ballard KD, Seaman HE, de Vries CS, Wright JT. Can symptomatology help in the diagnosis of endometriosis? Findings from a national case-control study--Part 1. BJOG Int J Obstet Gynaecol 2008;115(11):1382-91. https://doi.org/10.1111/j.1471-0528.2008.01878.x

4. Sarria-Santamera A, Orazumbekova B, Terzic M, Issanov A, Chaowen C, Asúnsolo-del-Barco A. Systematic review and meta-analysis of incidence and prevalence of endometriosis. Healthcare 2020;9(1). https://doi.org/10.3390/healthcare9010029

5. Ferrario E. Association of ovarian endometriosis and dermoid cyst. Minerva Ginecol 1960;12:570-2.

6. Taylor LH, Madhuri TK, Walker W, Morton K, Tailor A, Butler-Manuel S. Decidualisation of ovarian endometriomas in pregnancy: a management dilemma. A case report and review of the literature. Arch Gynecol Obstet 2015;291(5):961-8.

https://doi.org/10.1007/s00404-014-3531-y

7. Caruso ML, Pirrelli M. A rare association between ovarian endometriosis and bilateral ovarian teratoma. Case report. Minerva Ginecol 1997;49(7-8):341-3.

8. Frederick J, DaCosta V, Wynter S, Tenant I, McKenzie C, McDonald Y. Endometriosis co-existing with bilateral dermoid cysts of the ovaries treated by laparoscopy. West Indian Med J 2003;52(2):179-81.

9. van der Merwe JL, Siebert I, van Wyk AC. Rare case of perplexing ovarian endometriosis. Fertil Steril 2010;94(5):1910. e17-19.

https://doi.org/10.1016/j.fertnstert.2010.03.024

10. Chen T, Kuo H, Shyu S, Chu C, Chang T. Endometriosis coexisting with dermoid cyst in a single ovary: a case report. Chin Med J (Engl) 2011;124(4):627-30.
11. Prorocic M, Tasic L, Vasiljevic M, Jurisic A, Smiljkovic OD, Raznatovic S, et al. Simultaneous dermoid cyst and endometriosis in the same ovary: a case report. Clin Exp Obstet Gynecol 2013;40(3):457-9.

12. Chae H, Rheu C. Endometriosis coexisting with mature cystic teratoma in the same ovary and ectopic pregnancy of left fallopian tube: a rare coexistence. Clin Case Rep 2015;3(5):315-8. https://doi.org/10.1002/ccr3.118

13. Hwang JY, Lee MH, Lee JH, Kim DH, Song SH. A Case of unilateral endometriosis coexisting with struma ovarii in bilateral ovarian teratoma. J Minim Invasive Gynecol 2018;25(6):941-3. https://doi.org/10.1016/j.jmig.2017.11.021

14. Kıyak H, Kadiroğulları P, Karacan T, Seçkin K, Karatas S. Endometrioma coexisting with dermoid tumor in a single ovary presenting as atypical endometrioma. JSLS J Soc Laparoendosc Surg / Soc Laparoendosc Surg 2019.

15. Chae H. Coexistence of endometriosis in women with mature cystic ovarian teratoma may not be rare. J Gynecol Obstet Hum Reprod 2020;49(9):101786.

https://doi.org/10.1016/j.jogoh.2020.101786

16. Carpinello OJ, Sundheimer LW, Alford CE, Taylor RN, DeCherney AH. Endometriosis. Endotext. South Dartmouth (MA): MDText.com, Inc 2000. http://www.ncbi.nlm.nih.gov/ books/NBK278996/

17. Liu X, Long Q, Guo S-W. Surgical history and the risk of endometriosis: a hospital-based case-control study. Reprod Sci Thousand Oaks Calif 2016;23(9):1217-24.

https://doi.org/10.1177/1933719116632921

18. Lietuvos akušerių ginekologų draugijos (LAGD) valdybos sudaryta specialistų darbo grupè. Endometriozès diagnostikos ir gydymo rekomendacijos. 2011.

19. Hoyle AT, Puckett Y. Endometrioma. StatPearls Publishing 2021. https://www.ncbi.nlm.nih.gov/books/NBK559230/.

20. Houry D, Abbott JT. Ovarian torsion: a fifteen-year review. Ann Emerg Med 2001;38(2):156-9.

https://doi.org/10.1067/mem.2001.114303

21. Cao H, You D, Lan Z, Ye H, Hou M, Xi M. Prognostic value of serum and tissue HE4 expression in ovarian cancer: a systematic review with meta-analysis of 90 studies. Expert Rev Mol Diagn 2018;18(4):371-83.

https://doi.org/10.1080/14737159.2018.1457436

22. Atri M, Alabousi A, Reinhold C, Akin EA, Benson CB, Bhosale PR, ir kt. ACR Appropriateness criteria ${ }^{\circledR}$ clinically suspected adnexal mass, no acute symptoms. J Am Coll Radiol 2019;16(5):S77-93.

https://doi.org/10.1016/j.jacr.2019.02.011

23. Moro F, Leombroni M, Testa AC. Ultrasound imaging in endometriosis. Obstet Gynecol Clin North Am 2019;46(4):643-59. https://doi.org/10.1016/j.ogc.2019.07.004

24. Umaria N, Olliff JF. Imaging features of pelvic endometriosis. Br J Radiol 2001;74(882):556-62. 
https://doi.org/10.1259/bjr.74.882.740556

25. Saba L, Guerriero S, Sulcis R, Virgilio B, Melis G, Mallarini G. Mature and immature ovarian teratomas: CT, US and MR imaging characteristics. Eur J Radiol 2009;72(3):454-63.

https://doi.org/10.1016/j.ejrad.2008.07.044

26. Wolfman W, Thurston J, Yeung G, Glanc P. Guideline No. 404: initial investigation and management of benign ovarian masses. J Obstet Gynaecol Can 2020;42(8):1040-1050.e1. https://doi.org/10.1016/j.jogc.2020.01.014

27. Chun S, Cho HJ, Ji YI. Comparison of early postoperative decline of serum anti Müllerian hormone levels after unilateral laparoscopic ovarian cystectomy between patients categorized according to histologic diagnosis. Taiwan J Obstet Gynecol 2016;55(5):641-5.

https://doi.org/10.1016/j.tjog.2015.06.016

28. Karadağ C, Demircan S, Turgut A, Çalışkan E. Effects of laparoscopic cystectomy on ovarian reserve in patients with endometrioma and dermoid cyst. Turk J Obstet Gynecol 2020;17(1):15-20.

https://doi.org/10.4274/tjod.galenos.2020.37605

29. Henes M, Engler T, Taran F-A, Brucker S, Rall K, Janz B, ir kt. Ovarian cyst removal influences ovarian reserve dependent on histology, size and type of operation. Womens Health Lond Engl. 2018;14:1745506518778992.

https://doi.org/10.1177/1745506518778992

30. Kostrzewa M, Stachowiak G, Zyła M, Kolasa-Zwierzchowska D, Szpakowski A, Nowak M, ir kt. Women's fertility after laparoscopic cystectomy of endometrioma and other benign ovarian tumors - a 24-month follow-up retrospective study. Neuro Endocrinol Lett 2016 ;37(4):295-300.
31. Moridi A, Arab M, Fazli G, Khayamzadeh M. Clinical points in dermoid cyst management: a review article. J Obstet Gynecol Cancer Res Gynecol Cancer Res 2016, 1(3).

https://doi.org/10.17795/ogcr-10034

\section{UNILATERAL OVARIAN ENDOMETRIAL AND DERMOID CYSTS: CASE REPORT}

\section{Tavoraitė, D. Bartkevičienè}

Keywords: endometrioma; teratoma; dermoid; unilateral. Summary

Although the incidence of endometriomas and dermoid cysts among premenopausal women is high, the unilateral coexistence of these cysts is rare. We report a case of a unilateral complex endometrioid and dermoid ovarian cyst accidentally detected during a routine check, measuring up to $12 \mathrm{~cm}$. The patient did not report any typical ovarian cyst symptoms such as pelvic pain. There are 11 similar cases registered in the database of PubMed. Most of the dermoids are asymptomatic, however only $33 \%$ of endometriosis do not cause symptoms. Ultrasound and magnetic resonance imaging modalities are used in diagnostics. The management of ovarian cysts depends on the size and the symptoms. Laparoscopic cystectomy is advised for preserving the ovarian reserve and fertility for young women.

Correspondence to: daivabartk@gmail.com

Gauta 2021-05-18 